\title{
Indicators of Variability of Water Flow Rate in the Piwonia River
}

\author{
Antoni Grzywna' \\ 1 University of Life Sciences in Lublin, Akademicka 13, 20-033 Lublin, Poland \\ e-mail: antoni.grzywna@up.lublin.pl
}

\begin{abstract}
The paper presents the variability of the Piwonia River flows in the Parczew profile (catchment area of $391 \mathrm{~km}^{2}$ ) in hydrological years 2009/10-2015/16. On the basis of the monthly flow and daily water level measurements, flow-level curves and hydrograms of water flows were drawn. The analysis of the weather conditions in the catchment area showed that in the analyzed period there were two very wet years $(2010,2014)$, three wet years $(2011$, $2013,2016)$, one normal year (2012) and one dry year (2015). The total of annual precipitation in very wet years was $150 \mathrm{~mm}$ (130\% of the norm) higher than the average for multi-years, and in the dry year it was $60 \mathrm{~mm}(86 \%$ of the norm) lower. The intensity of instantaneous flows ranged from $0.26 \mathrm{~m}^{3} \cdot \mathrm{s}^{-1}$ in 2015 to $5.5 \mathrm{~m}^{3} \cdot \mathrm{s}^{-1}$ in 2010 . The average annual flow of the river in multi-years was $\mathrm{SSQ}=1.68 \mathrm{~m}^{3} \cdot \mathrm{s}^{-1}$ and ranged from $1.19 \mathrm{~m}^{3} \cdot \mathrm{s}^{-1}$ in 2015 (dry in terms of precipitation) to $2.13 \mathrm{~m}^{3} \cdot \mathrm{s}^{-1}$ in 2010 (very wet). The direct reasons for the variability of river flows are: weather conditions, retention capacity of lakes and fish ponds, and exploitation of the hydrotechnical structures. The hydrological year 2014/15 was characterized by the highest variability of flows, while the lowest variability was recorded in the hydrological year 2010/11.
\end{abstract}

Keywords: Piwonia River, water flow, indicators of variation

\section{INTRODUCTION}

Water is a basic element determining life on Earth and affecting the biodiversity of ecosystems. The water resources in a given area are shaped by terrain and climate conditions, mainly by precipitation and hypsometric diversification. The availability of water of specific quantity and quality on time, satisfying the requirements, is an essential element of sustainable economic growth [Mosiej et al 2011, Mioduszewski 2002, Somorowski 2003]. The Lublin Voivodeship is characterized by relatively small water resources. The average unit outflow is $3.98 \mathrm{dm}^{3} \cdot \mathrm{s}^{-1} \cdot \mathrm{km}^{-2}$; it is maintained at the average level for the Lublin upland region. Its size is $1.6 \mathrm{dm}^{3} \cdot \mathrm{s}^{-1} \cdot \mathrm{km}^{-2}$ lower than the value for Poland [Michalczyk and Wilgat 1998]. Water shortages occur even in average years. The northern part of the voivodeship is classified as a territory particularly exposed to drought and requiring an immediate increase in water retention [Hobot 2008, Chmielewski 2009].
The occurrence of significant water flow variations in watercourses is one of the basic criteria for the selection of a uniform surface water body for diagnostic monitoring. The classification of ecological status is based on the biological elements as well as supporting the physicochemical and hydromorphological elements. One important hydromorphological element is the hydrological regime of the river. Systematic measurements of water levels and flows are required to determine the hydrological regime [Kanclerz 2010].

The hydrological regime of controlled rivers, but not always of a uniform surface water surface [Łoś 2005, Pierzgalski 2010], can be determined from the current data on water levels and characteristic flows published in synthetic studies. The aim of the paper was to present the variability of water flows in the Piwonia River for the Parczew profile in hydrological years 2009/10-2015/16. 


\section{MATERIALS AND METHODS}

This article presents the results of field research and observations conducted in the Piwonia River basin for the Parczew profile. Currently, the Piwonia River is an uncontrolled river - there are no hydrological measurements (Fig. 1) [Łoś 2005]. Field research and observations included:

- daily surface water levels - registered by means of a digital recorder, daily precipitation - measurements by a station in Sosnowica, monthly flow rate measurements - hydrometric meter,

- periodic research of the river bed geometry geodetic measurements.

The measurements of water levels and flows allowed determining the flow curve of the Piwonia River in the Parczew profile. The flow rate curves were determined, and then daily flows were selected based on the level-flow relationship. A series of daily data of the Piwonia River flows was obtained, which enabled compiling the characteristic monthly and annual values. For the years 2008-2016, the flow rate was calculated on the basis of available measurements for the multiyears $1970-1983$ by means of the hydrological analogy method [Byczkowski 1999].

The analysis of precipitation distribution was carried out on the basis of measurement results from hydrological years 2009/10-2015/16. The data was compared with the data from the multiyears 1985-2014 (30 years of observation). The variability of the Piwonia River flows was estimated by:

- irregularity coefficient

$$
\alpha=\frac{W Q}{N Q}
$$

- coefficient of variation

$$
C=\frac{\delta}{S Q}
$$

- factor of variation

$$
\psi=\frac{k_{3}-k_{1}}{2 k_{2}}
$$

- relative amplitude

$$
A=\frac{W Q-N Q}{S Q}
$$

- monthly factor

$$
M=\frac{S Q M}{S Q R}
$$

where: $N Q-$ the lowest flow in the year,

$W Q$ - the highest flow in the year,

$S Q R$ - average annual flow,

SQM - average monthly flow,

$\delta$ - standard deviation,

$k 1$ - lower quartile ( $25 \%$ of observations),

$\mathrm{k} 2$ - median ( $50 \%$ of observations),

$k 3$ - upper quartile ( $75 \%$ of observations)

The Piwonia River has an inconsistent string of hydrological observations. Initially, from 1956, periodic hydrometric measurements (average and maximum depth and velocity) of the Piwonia River were carried out in the Parczew profile. This profile is located on $10.2 \mathrm{~km}$ of the river course and it controls the catchment area of $391 \mathrm{~km}^{2}$. Then, in the years 1970-90, daily measurements of water levels and flows were conducted in this profile. In turn, daily measurements of water levels in the Sosnowica profile were conducted only in the years 1975-83. This profile is located on the $37 \mathrm{~km}$ of the river course and controls the catchment area of $122 \mathrm{~km}^{2}$ [Rocznik 1984].

\section{RESULTS}

The Piwonia River basin is located in the Western Polesie mesoregion and covers the following macroregions: Łęczna-Włodawa Lakeland, Zaklęsłość Sosnowicka, Parczewska Plain. The catchment is located in the $9^{\text {th }}$ LubartówParczew climate region. The Piwonia River is a right-bank tributary of the Tyśmienica River, to which it escapes on $38+100 \mathrm{~km}$. According to the European coding system for hydrographic units, it is assigned the code 2482 [Kondracki 2000, Czarnecka 2005]. The total area of the river basin is $579.3 \mathrm{~km}^{2}$, while that of the Parczew profile is 391 $\mathrm{km}^{2}$. The source of the river is currently located in Lake Uściwierzek at an altitude of $169 \mathrm{~m}$ above sea level. The length of the river measured up to 
the estuary located at an altitude of $137 \mathrm{~m}$ above sea level is $62.7 \mathrm{~km}$. The height difference is 32 $\mathrm{m}$, which corresponds to an average river slope of $0.5 \%$. There are eleven lakes in the river basin with a total area of 920 ha, which gives a $0.6 \%$ lakes area index [Michalczyk and Wilgat 1998]. There are 16 hydrotechnical structures ( 8 weirs, 8 degrees) and 3 pond complexes (Górki, Sosnowica, Libiszów) over the entire Piwonia River.

The catchment basin is located in Western Polesie that is a region characterized by the lowest precipitation levels in Poland. In the years 1985-2014, the average annual rainfall was $527 \mathrm{~mm}$, of which $169 \mathrm{~mm} \mathrm{(32 \% )}$ was for the winter half-year (XI-IV) and for the summer halfyear (V-X) - $358 \mathrm{~mm}(68 \%)$. At the same time, in this area there are large water losses due to evaporation. The evapotranspiration calculated for Western Polesie, in the years 2010-14 amounted to $516 \mathrm{~mm}$ [Grzywna et al. 2016, Grzywna and Kowalczyk-Juśko 2018]. The analyzed period of seven hydrological years was characterized by a high variability of precipitation (Table 1). During that period, the level of precipitation was $598 \mathrm{~mm}$, which was $70 \mathrm{~mm}$ higher than the average for multi-years. The highest precipitation levels were recorded in the hydrological year 2013/14, when they amounted to $683 \mathrm{~mm}$ and were $30 \%$ higher

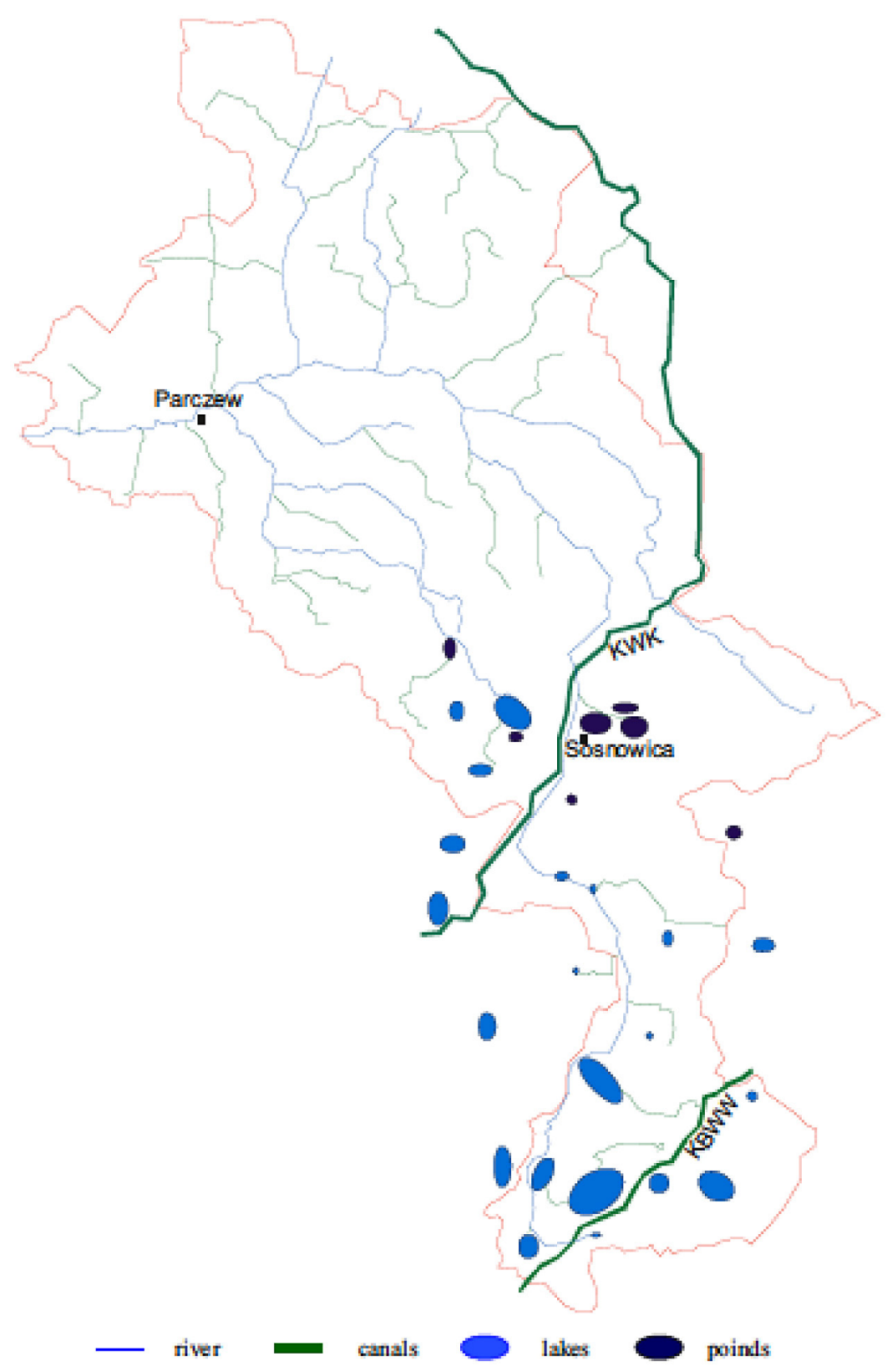

Fig. 1. Basic network of the Piwonia River basin 
Table 1. Periodic precipitation sums [mm]

\begin{tabular}{|c|c|c|c|c|c|c|}
\hline \multirow{2}{*}{ Year } & \multicolumn{2}{|c|}{$\mathrm{XI-IV}$} & \multicolumn{2}{|r|}{$\mathrm{V}-\mathrm{X}$} & \multicolumn{2}{|c|}{$\mathrm{XI}-\mathrm{X}$} \\
\hline & $\mathrm{mm}$ & class & $\mathrm{mm}$ & class & $\mathrm{mm}$ & class \\
\hline $2009 / 10$ & 134 & Dry & 541 & Extremely wet & 675 & Very wet \\
\hline 2010/11 & 167 & Normal & 486 & Very wet & 653 & Wet \\
\hline $2011 / 12$ & 148 & Dry & 373 & normal & 521 & Normal \\
\hline $2012 / 13$ & 189 & Wet & 416 & Wet & 605 & Wet \\
\hline $2013 / 14$ & 193 & Wet & 490 & Very wet & 683 & Very wet \\
\hline $2014 / 15$ & 205 & Wet & 262 & Very dry & 467 & Dry \\
\hline $2015 / 16$ & 275 & Extremely wet & 335 & Normal & 610 & Wet \\
\hline Average & 187 & Normal & 411 & Wet & 598 & Wet \\
\hline 1985-2014 & 169 & Normal & 358 & Normal & 527 & Normal \\
\hline
\end{tabular}

than the average for multi-years. The lowest sums of precipitation were recorded in 2014/15 when they amounted to $467 \mathrm{~mm}$, which was $15 \%$ lower than the average for multi-years. In the hydrological winter half-year, the highest precipitation level occurred in 2015/16 - $275 \mathrm{~mm}$, and the lowest was recorded in 2009/10 - $134 \mathrm{~mm}$. Much higher variability of precipitation levels occurred in the summer half-year. Precipitation ranged from 262 $\mathrm{mm}$ in $2014 / 15$ ( $25 \%$ lower than the average) to $541 \mathrm{~mm}$ in $2009 / 10$ (55\% higher than the average for multi-years).

In seasonal terms, the leveling of flows is fairly large. The average annual flow for the multiyears 2010-2016 was $1.68 \mathrm{~m}^{3} \cdot \mathrm{s}^{-1}$, which corresponds to a unit outflow of $4.3 \mathrm{dm}^{3} \cdot \mathrm{s}^{-1} \cdot \mathrm{km}^{-2}$. The average flow in the winter half-year (XI-IV) was $1.1 \mathrm{~m}^{3} \cdot \mathrm{s}^{-1}$ and in summer $(\mathrm{V}-\mathrm{X}) 2.2 \mathrm{~m}^{3} \cdot \mathrm{s}^{-1}$. The average flow in the hydrological year ranged from
$0.72 \mathrm{~m}^{3} \cdot \mathrm{s}^{-1}$ in $2014 / 2015$ to 1.52 in $2013 / 2014$. The lowest average monthly flows dropped down to for $1 \mathrm{~m}^{3} \cdot \mathrm{s}^{-1}$, i.e. to $3 \mathrm{dm}^{3} \cdot \mathrm{s}^{-1} \cdot \mathrm{km}^{-2}$. In turn, the highest average monthly flows amounted to 2.9 $\mathrm{m}^{3} \cdot \mathrm{s}^{-1}$, i.e. to $12 \mathrm{dm}^{3} \cdot \mathrm{s}^{-1} \cdot \mathrm{km}^{-2}$ (Fig. 2). Their highest values were observed in March, while the lowest ones in June and July. The maximum flow during the observation period of $5.5 \mathrm{~m}^{3} \cdot \mathrm{s}^{-1}$ occurred in June 2010 after very high levels of precipitation amounting to $220 \mathrm{~mm}$ per month. The minimum flow observation of $0.26 \mathrm{~m}^{3} \cdot \mathrm{s}^{-1}$ occurred in July 2015. The collected hydrometric materials document a small variability of water levels, indicating a fairly stable supply of groundwater to the river (Fig. 3).

The maximum coefficient and flow variability index were recorded in 2015 that was a dry year in terms of precipitation. In turn, their minimum values were recorded in the very wet year 2011

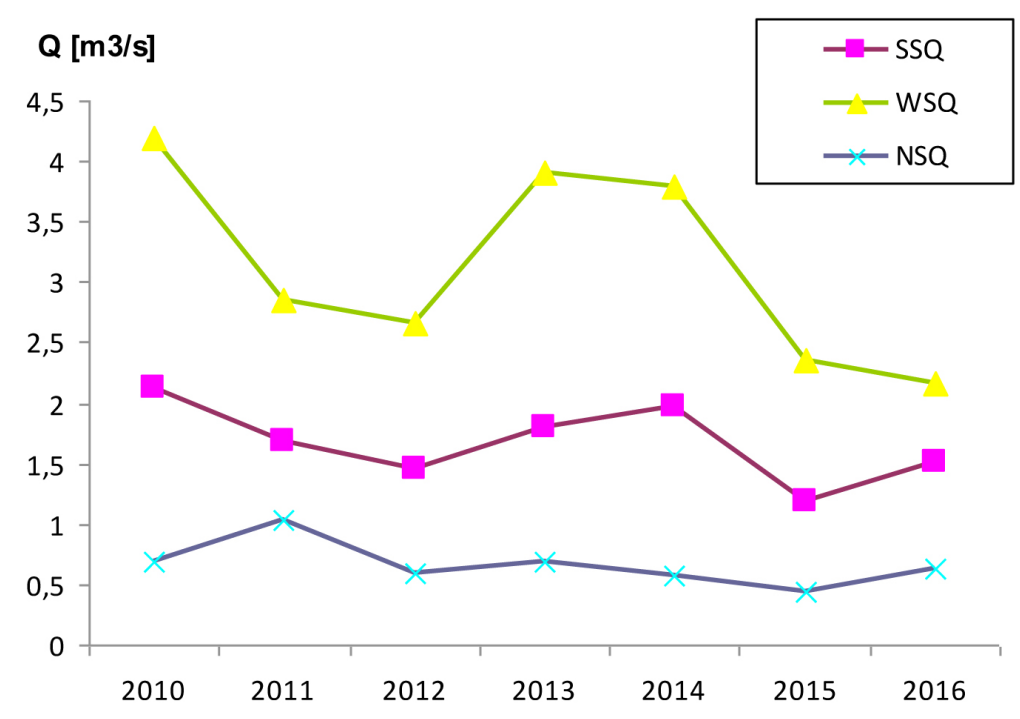

Fig. 2. The course of average annual characteristic flows

SSQ - average annual flow, WSQ - the maximum average monthly flow,

NSQ - the minimum average monthly flow 


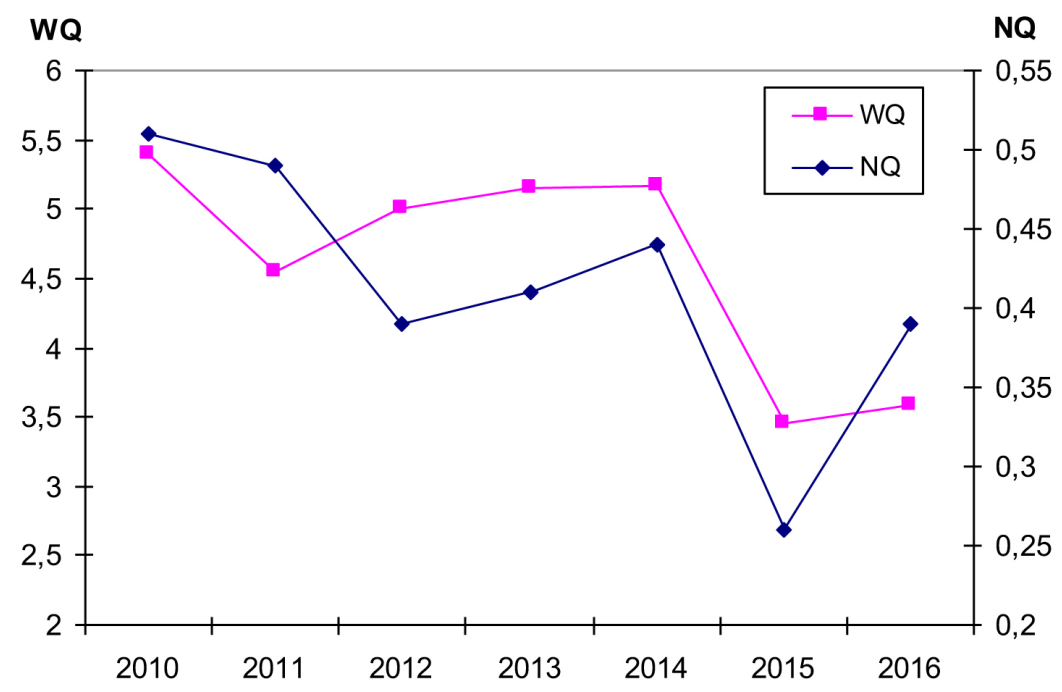

Fig. 3. Fluctuations of extreme annual characteristic flows

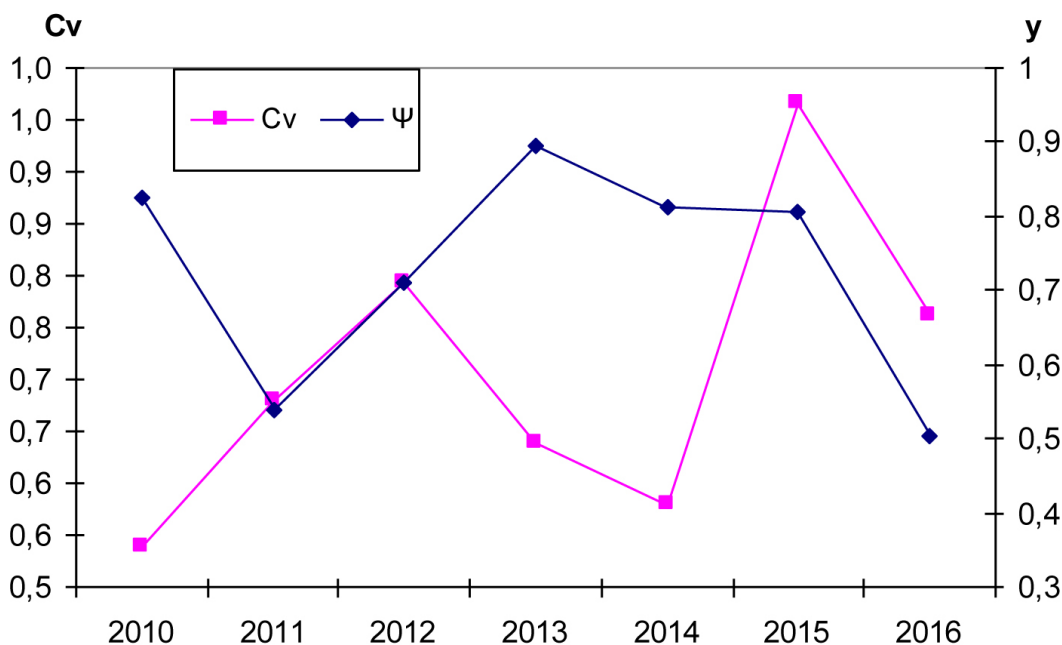

Fig. 4. Fluctuation of the coefficient of variation $\left(\mathrm{C}_{\mathrm{v}}\right)$ and factor of variation $(\psi)$ of flows in the Piwonia River

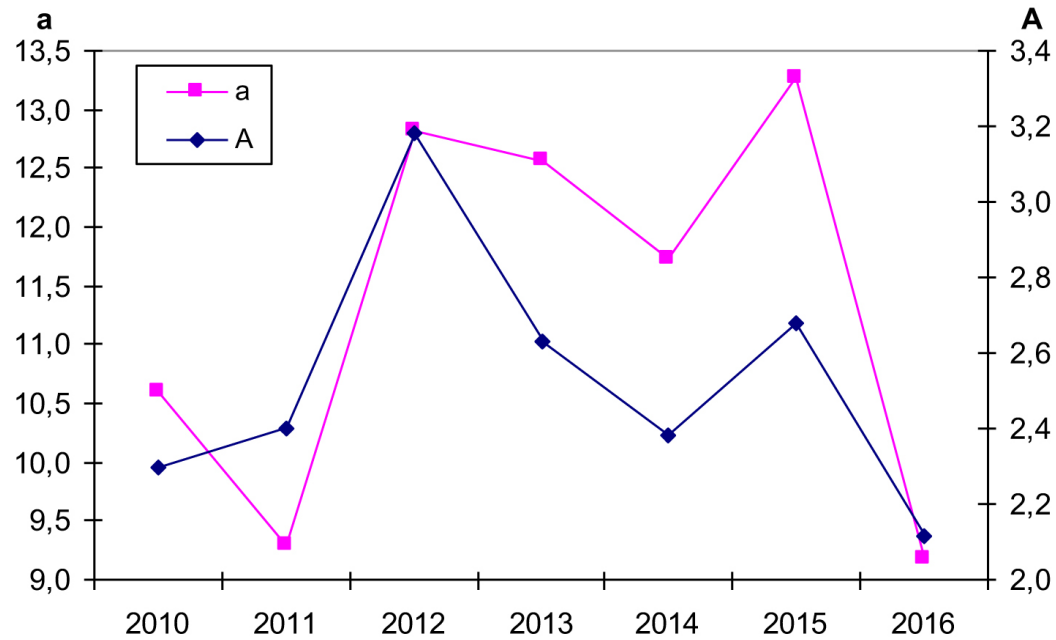

Fig. 5. The course of the relative amplitude (A) and the coefficient of irregularity (a) of flows in the Piwonia River 
(Fig. 4). The maximum relative amplitude was recorded in the normal year 2012, while the maximum irregularity coefficient was recorded in the wet year 2016 (Fig. 5).

The combined mean and minimum monthly flow values indicate a long-term variability of water resources. In the years 2010-2016, the flows above the average value were maintained over the next few months. Particularly high flows occurred in the years 2013-2014. Conversely, the lowest flow was recorded in the summer months of 2012 and 2016. The values of average, maximum and minimum monthly flows unambiguously indicate a very large share of groundwater in the total outflow, which was estimated at $80 \%$ during the study period. It results from the good soil infiltration conditions, which retains precipitation within the aeration horizon.

\section{CONCLUSIONS}

1. In the period 2010-2016, in terms of precipitation, there were two very wet years, three wet years, one normal year and one dry year in the Piwonia River basin.

2. The average annual flow of the river in multiyears was $\mathrm{SSQ}=1.68 \mathrm{~m}^{3} \cdot \mathrm{s}^{-1}$ and ranged from $1.19 \mathrm{~m}^{3} \cdot \mathrm{s}^{-1}$ in 2015 (dry in terms of precipitation) to $2.13 \mathrm{~m}^{3} \cdot \mathrm{s}^{-1}$ in 2010 (very wet). The direct reasons for the variability of river flows include: weather conditions, retention capacity of lakes and ponds, and exploitation of hydrotechnical structures.

3. The largest variability of flows was found in the hydrological year 2014/15, while the lowest variability was observed in the hydrological year 2010/11.

\section{REFERENCES}

1. Byczkowski A. 1999. Hydrologia. PWN Warszawa.

2. Chmielewski T.J. (red.) 2009. Ecology landscapes hydrogenic Biosphere Reserve "Western Polesie". Uniwersytet Przyrodniczy w Lublinie.

3. Czarnecka H. (red.) 2005. Atlas podziału hydrograficznego Polski. IMGW Warszawa.

4. Grzywna A., Czarnecki Z., Węgorek T. 2016. Assessment of Components of the Water Balance of Drained Peatbog. Rocznik Ochrona Środowiska, 18, 519-530.

5. Grzywna A., Kowalczyk-Juśko A. 2018. The effect of adjustable outflow on the fluctuations in the level of surface and ground water. Journal of Ecological Engineering 19(2), 159-163.

6. Hobot A. (red.). 2008. Program wodnośrodowiskowy kraju. KZGW Warszawa.

7. Kanclerz J. 2010. Ocena zmienności natężenia przepływów rzeki Małej Wełny. Zeszyty Problemowe Postępów Nauk Rolniczych, 548, 267-274.

8. Kondracki J. 2000. Geografia regionalna Polski. PWN Warszawa.

9. Łoś M. 2005. Wybrane problemy wdrożenia Ramowej Dyrektywy Wodnej. Wiadomości Melioracyjne i Łąkarskie, 1, 8-11.

10. Michalczyk Z., Wilgat T. 1998. Stosunki wodne Lubelszczyzny. UMCS Lublin.

11. Mioduszewski W. 2002. Kształtowanie zasobów wodnych w obszarach rolniczych. Wiadomości Melioracyjne i Łąkarskie, 1, 39-41.

12. Mosiej J., Pierzgalski E., Jeznach J. 2011. Współczesne uwarunkowania gospodarowania wodą w obszarach wiejskich. Postępy Nauk Rolniczych, 1, 25-36.

13. Pierzgalski E. 2010. Zasoby wodne a rozwój rolnictwa. Studia i Raporty IUNG, 19, 91-105.

14. Rocznik hydrologiczny wód powierzchniowych w dorzeczu Wisły. 1984. IMGW Warszawa.

15. Somorowski Cz. (red.) 2003. Współczesne problemy melioracji. SGGW Warszawa. 